\title{
Optical control of NMDA receptors by azobenzene quaternary ammonium compounds
}

\section{Maxim V. Nikolaev, Daniil M. Strashkov, Mikhail N Ryazantsev ${ }^{\text {b }}$, Denis B. \\ Tikhonov a}

a Sechenov Institute of Evolutionary Physiology and Biochemistry of RAS, 194223, Thorez pr. 44, Saint Petersburg, Russia

b Institute of Chemistry, Saint Petersburg State University, 198504, Universitetskii pr.

26, Saint Petersburg, Russia

Corresponding author: Maxim V. Nikolaev, Sechenov Institute of Evolutionary Physiology and Biochemistry of RAS, 194223, Thorez pr. 44, Saint Petersburg, Russia e-mail: fmedfstud@gmail.com, phone: +79112576912

\section{Supplementary material}

(12 pages)

\section{Contents}

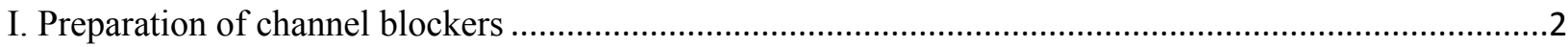

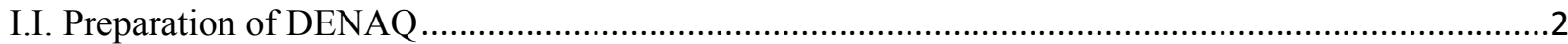

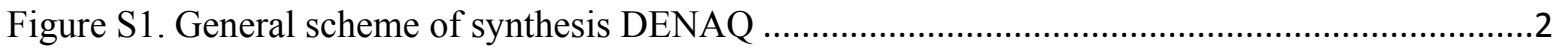

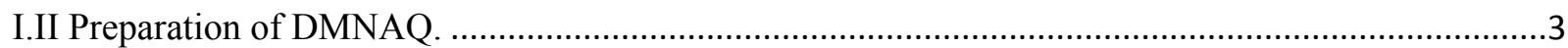

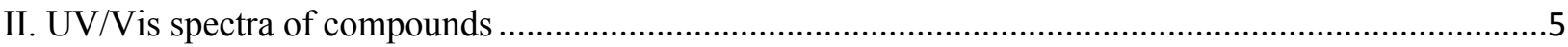

Figure S2: UV/Vis spectra of a)DENAQ and b)DMNAQ in the dark-adapted, all trans-state, in water

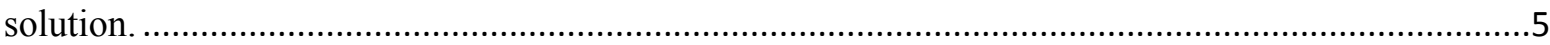

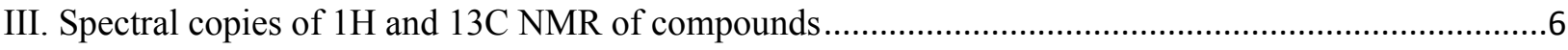

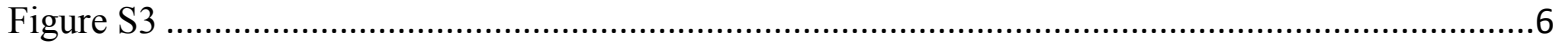

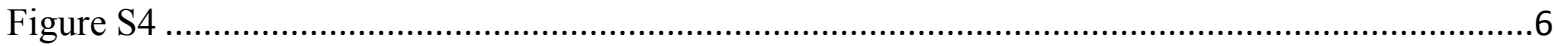

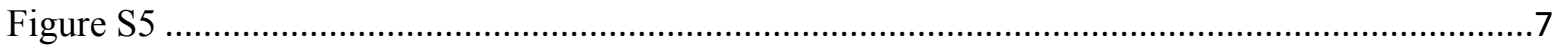

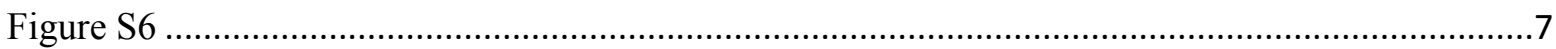

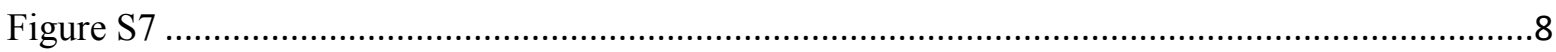

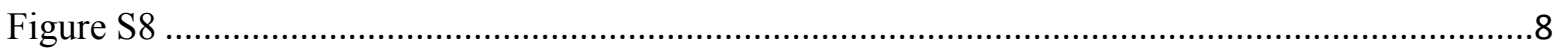


Figure S9 9

Figure S10 9

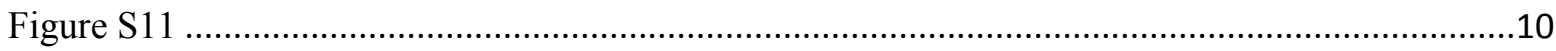

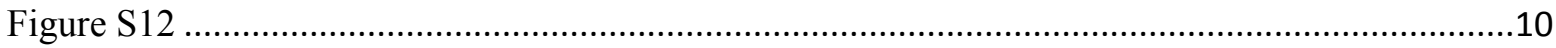

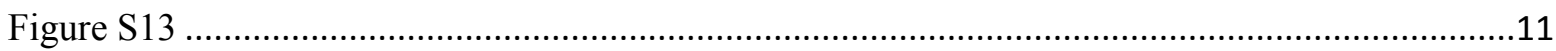

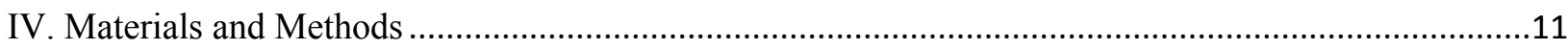

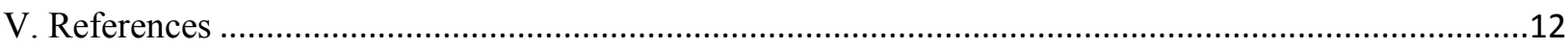

\section{Preparation of channel blockers}

\section{I.I. Preparation of DENAQ}<smiles>CCNc1ccc(N=Nc2ccc(N=Nc3ccc(N=Nc4ccc(N)cc4)cc3)cc2)cc1</smiles><smiles>CCN(CC)c1ccc(N=Nc2ccc(NC(=O)CCl)cc2)cc1</smiles><smiles>CCN(CC)CC(=O)Nc1ccc(N=Nc2ccc(N=Nc3ccc(NC(=O)CCl)cc3)cc2)cc1</smiles>

Figure S1. General scheme of synthesis DENAQ

$\boldsymbol{N}, \boldsymbol{N}$-diethyl-4-((4-nitrophenyl)diazenyl)aniline $\mathbf{2}$ was prepared according to the literature procedure [1] from $2 \mathrm{~g}(14.5 \mathrm{mmol})$ of 4-nitroaniline $1,1 \mathrm{~g}(14.5 \mathrm{mmol}) \mathrm{NaNO}_{2}$ and $2.16 \mathrm{~g}(14.5 \mathrm{mmol})$ of $N, N$-diethylaniline. The product was recrystallized from ethanol and used in the next step without further purification. The product yield was 1.86 g $(43 \%)$.

4-((4-aminophenyl)diazenyl)- $\mathbf{N}, \boldsymbol{N}$-diethylaniline $\mathbf{3}$ was prepared according to the literature procedure [1] from $1.5 \mathrm{~g}(5 \mathrm{mmol})$ of compound 2 and $2.4 \mathrm{~g}(10 \mathrm{mmol})$ of 
Na2S.9H2O with the yield of $0.735 \mathrm{~g}(55 \%) .{ }^{1} \mathrm{H}$ NMR (DMSO-d6, $\left.500 \mathrm{MHz}\right) \delta$ : 7.677.61 (2H, m), 7.58-7.53 (2H, m), 6.76-6.69 (2H, m), 6.67-6.61 (2H, m), 5.77 (2H, br. s.), $3.40(4 \mathrm{H}, \mathrm{q}, J=7.0 \mathrm{~Hz}), 1.12(6 \mathrm{H}, \mathrm{t}, J=7.0 \mathrm{~Hz}) \cdot{ }^{13} \mathrm{C} \mathrm{NMR}\left(\mathrm{CDCl}_{3}\right) \delta: 150.9,148.6$, $143.3,142.4,123.8,113.5,111.0,43.9,12.5$.

2-Chloro- $N$-(4-((4-(diethylamino)phenyl)diazenyl)phenyl)acetamide $4 . \quad$ To the solution of $268 \mathrm{mg}$ ( $1 \mathrm{mmol}$ ) of compound $3,284 \mathrm{mg}$ ( $3 \mathrm{mmol})$ of chloroacetic acid and $18 \mathrm{mg}(0.15 \mathrm{mmol})$ of DMAP in dichloromethane was slowly added solution of $310 \mathrm{mg}$ $(1.5 \mathrm{mmol})$ DCC in dichloromethane. The reaction mixture was cooled in an ice bath while adding. Then the mixture was stirred for 2 hours at room temperature. Formed DCU was filtered, then the solvent was distilled. The reaction products were dissolved in 1,4-dioxane, the insoluble precipitate was filtered, and dioxane was distilled off. The products were purified by the method of column chromatography on silica gel (DCM to DCM:EtOAc 4:1). The product yield was $175 \mathrm{mg}(68 \%) .{ }^{1} \mathrm{H}$ NMR $\left(\mathrm{CDCl}_{3}, 500 \mathrm{MHz}\right) \delta$ : 8.35 (1H, br.s.), 7.89-7.81 (4H, m), 7.69-7.60 (2H, m), $6.73(2 \mathrm{H}, \mathrm{d}, \mathrm{J}=8.8 \mathrm{~Hz}), 4.21(2 \mathrm{H}$, s), $3.41(4 \mathrm{H}, \mathrm{q}, \mathrm{J}=7.1 \mathrm{~Hz}), 1.23(6 \mathrm{H}, \mathrm{t}, \mathrm{J}=7.1 \mathrm{~Hz}) .{ }^{13} \mathrm{C} \mathrm{NMR}\left(\mathrm{CDCl}_{3}\right) \delta: 163.6,150.3$, 137.4, 125.3, 123.0, 120.1, 119.5, 111.1, 44.8, 42.9, 12.6. HRMS (ESI-TOF): $\mathrm{m} / \mathrm{z}$ calcd for $\mathrm{C}_{18} \mathrm{H}_{22} \mathrm{ClN} 4 \mathrm{O}[\mathrm{M}+\mathrm{H}]^{+}$345.1477; found 345.1477.

\section{2-((4-((4-(diethylamino)phenyl)diazenyl)phenyl)amino)- $N, N, N$-triethyl-2-oxoethan-}

1-aminium chloride (DENAQ) 5. To the mixture of $185 \mathrm{mg}(0.25 \mathrm{mmol})$ of compound 3 in $10 \mathrm{~mL}$ of DMF was slowly added $0.3 \mathrm{~mL}$ of $\mathrm{Et}_{3} \mathrm{~N}$ in $3 \mathrm{~mL}$ of DMF. Reaction mixture was heated to $50{ }^{\circ} \mathrm{C}$ and stirred overnight at this temperature. The solvent was reduced in vacuum, reaction products were purified with column chromatography (acetone - acetone:MeOH 1:10). The initial compound was isolated and reused. The yield was $93 \mathrm{mg}(39 \%){ }^{1} \mathrm{H}$ NMR (DMSO-d6, $\left.500 \mathrm{MHz}\right) \delta$ : 1.13-1.18 (6H, m), 1.28-1.34 (9H, $\mathrm{m})$, 3.42-3.51 (4H, m), 3.53-3.62 (6H, m), 4.19-4.25 (2H, m), 6.79-6.83 (2H, m), 7.737.79 (4H, m), 7.84-7.89 (2H, m), 10.47 (1H, br.s). HRMS (ESI-TOF): $\mathrm{m} / \mathrm{z}$ calcd for $\mathrm{C}_{24} \mathrm{H}_{36} \mathrm{~N}_{5} \mathrm{O}^{+}$410.2914; found 410.2914. UV/Vis $\left(\mathrm{H}_{2} \mathrm{O}\right): \lambda_{\max }=473 \mathrm{~nm}$.

\section{I.II Preparation of DMNAQ.}

The methyl analogue (DMNAQ) was synthesized according to the same scheme as DENAQ (Fig. S1). 
$\boldsymbol{N}, \boldsymbol{N}$-dimethyl-4-((4-nitrophenyl)diazenyl)aniline 6 was prepared according to the literature procedure from $16.9 \mathrm{~g}(0.12 \mathrm{~mol})$ of 4-nitroaniline, $8.28 \mathrm{~g}(0.12 \mathrm{~mol})$ of $\mathrm{NaNO}_{2}$, and $14.52 \mathrm{~g}(0.12 \mathrm{~mol})$ of $N, N$-dimethylaniline with the yield of $14.56 \mathrm{~g}(45 \%)$. The product was washed twice with water, recrystallized from EtOH. ${ }^{1} \mathrm{H}$ NMR (DMSOd6, $500 \mathrm{MHz}) \delta: 8.28-8.24(2 \mathrm{H}, \mathrm{m}), 7.90-7.81(4 \mathrm{H}, \mathrm{m}), 6.79-6.75(2 \mathrm{H}, \mathrm{m}), 3.11(6 \mathrm{H}, \mathrm{s})$. HRMS (ESI-TOF): $\mathrm{m} / \mathrm{z}$ calcd for $\mathrm{C}_{14} \mathrm{H}_{15} \mathrm{~N}_{4} \mathrm{O}_{2}[\mathrm{M}+\mathrm{H}]^{+}$271.1190; found 271.1190.

4-((4-Aminophenyl)diazenyl)- $\mathbf{N}, \mathbf{N}$-dimethylaniline 7. To the solution of $2.0 \mathrm{~g}$ of compound 6 in mixture 1,4-dioxane $/ \mathrm{H}_{2} \mathrm{O}$ was added $3.6 \mathrm{~g}$ (2 eq.) of $\mathrm{Na}_{2} \mathrm{~S} \cdot 9 \mathrm{H}_{2} \mathrm{O}$. The mixture was boiled with stirring for 3 hours. Then the solvent was distilled in a vacuum, the products were dissolved in $50 \mathrm{ml}$ of water, and extracted with 3 x $50 \mathrm{ml}$ of ethyl acetate. The organic extracts were washed with water, brine and dried over anhydrous $\mathrm{Na}_{2} \mathrm{SO}_{4}$. The product was isolated by flash chromatography using the mixture of dichloromethane/hexane $1: 1$ as an eluent. The yield was $0.93 \mathrm{~g}(52 \%) .{ }^{1} \mathrm{H} \mathrm{NMR}\left(\mathrm{CDCl}_{3^{-}}\right.$ DMSO-d6 mixture, $500 \mathrm{MHz}) \delta: 7.71-7.65(2 \mathrm{H}, \mathrm{m}), 7.62-7.58(2 \mathrm{H}, \mathrm{m}), 6.69-6.63(4 \mathrm{H}$, m), 4.59 (2H, br.s.), $2.99(6 \mathrm{H}, \mathrm{s}) .{ }^{13} \mathrm{C} \mathrm{NMR}\left(\mathrm{CDCl}_{3} / \mathrm{DMSO}\right.$ mixture, $\left.125 \mathrm{MHz}\right) \delta$ : 151.0 , 149.0, 144.4, 143.0, 123.5, 123.4, 113.8, 111.1, 39.8. HRMS (ESI-TOF): m/z calcd for $\mathrm{C}_{14} \mathrm{H}_{17} \mathrm{~N}_{4}[\mathrm{M}+\mathrm{H}]^{+}$241.1448; found 241.1451.

2-Chloro- $\mathrm{N}$-(4-((4-(dimethylamino)phenyl)diazenyl)phenyl)acetamide $\quad 8 . \quad$ This compound was prepared according to the same procedure for compound 4 from $0.5 \mathrm{~g}$ $(2.08 \mathrm{mmol})$ of aniline $6,0.59 \mathrm{~g}(6.25 \mathrm{mmol})$ of cloroacetic acid, $0.645 \mathrm{~g}(3.12 \mathrm{mmol})$ of DCC, and $0.038 \mathrm{~g}(0.31 \mathrm{mmol})$ of DMAP with the yield of $0.477 \mathrm{~g}(73 \%) .{ }^{1} \mathrm{H}$ NMR

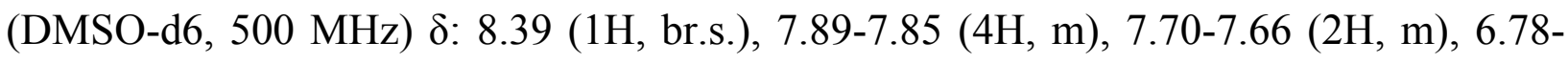
$6.74(2 \mathrm{H}, \mathrm{m}), 4.22(2 \mathrm{H}, \mathrm{s}), 3.09(6 \mathrm{H}, \mathrm{s}) .{ }^{13} \mathrm{C}$ NMR (DMSO-d6, $\left.125 \mathrm{MHz}\right) \delta: 163.7$, 157.0, 152.4, 143.9, 137.6, 125.0, 123.2, 120.1, 111.6, 42.9, 40.3. HRMS (ESI-TOF): $\mathrm{m} / \mathrm{z}$ calcd for $\mathrm{C}_{16} \mathrm{H}_{18} \mathrm{ClN}_{4} \mathrm{O}[\mathrm{M}+\mathrm{H}]^{+}:$317.1164; found 317.1164 .

\section{2-((4-((4-(Dimethylamino)phenyl)diazenyl)phenyl)amino)- $N, N, N$-triethyl-2-}

oxoethan-1-aminium chloride (DMNAQ) 9. Compound 9 was obtained according to the general procedure from $200 \mathrm{mg}$ of compound $\mathbf{8}$ with the yield of $121 \mathrm{mg}(46 \%) .{ }^{1} \mathrm{H}$

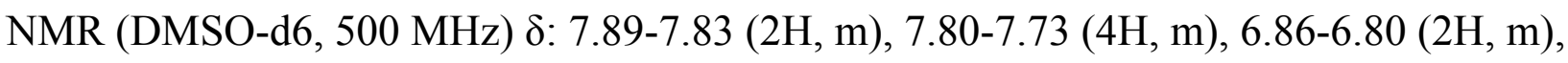
$4.60(2 \mathrm{H}, \mathrm{s}), 3.54(4 \mathrm{H}, \mathrm{q}, J=7.1 \mathrm{~Hz}), 3.05(6 \mathrm{H}, \mathrm{s}), 1.28(9 \mathrm{H}, \mathrm{t}, J=7.1 \mathrm{~Hz}) .{ }^{13} \mathrm{C}$ NMR (DMSO-d6, $125 \mathrm{MHz}$ ) $\delta: 163.0,152.3,148.5,142.6,140.4,124.5,122.5,120.4,111.6$, 
56.6, 53.9, 25.3, 7.5. HRMS (ESI-TOF): $\mathrm{m} / \mathrm{z}$ calcd for $\mathrm{C}_{22} \mathrm{H}_{32} \mathrm{~N}_{5} \mathrm{O}^{+}: 382.2601$; found 382.2601. UV/Vis $\left(\mathrm{H}_{2} \mathrm{O}\right): \lambda_{\max }=459 \mathrm{~nm}$.

\section{UV/Vis spectra of compounds}
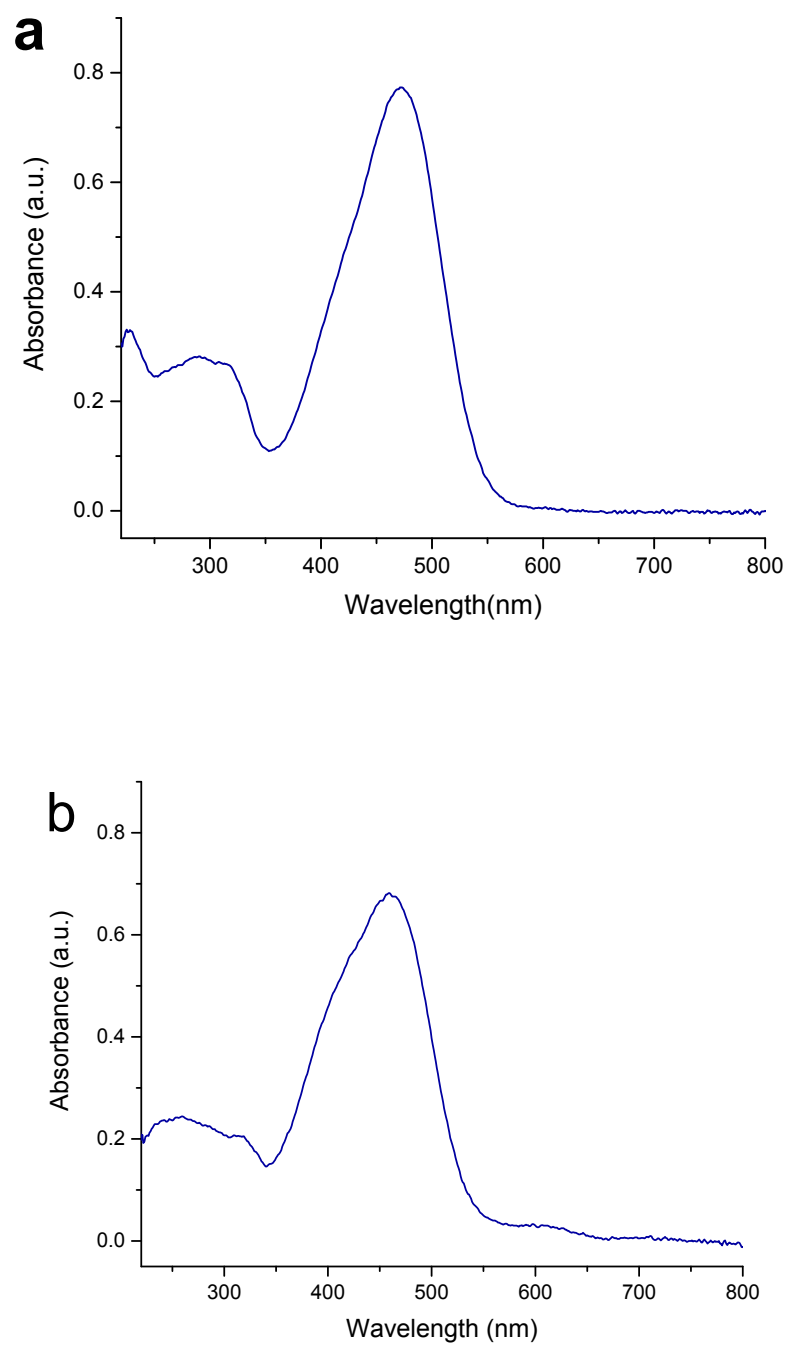

Figure S2: UV/Vis spectra of a)DENAQ and b)DMNAQ in the dark-adapted, all trans-state, in water solution. 
III. Spectral copies of $1 \mathrm{H}$ and $13 \mathrm{C}$ NMR of compounds

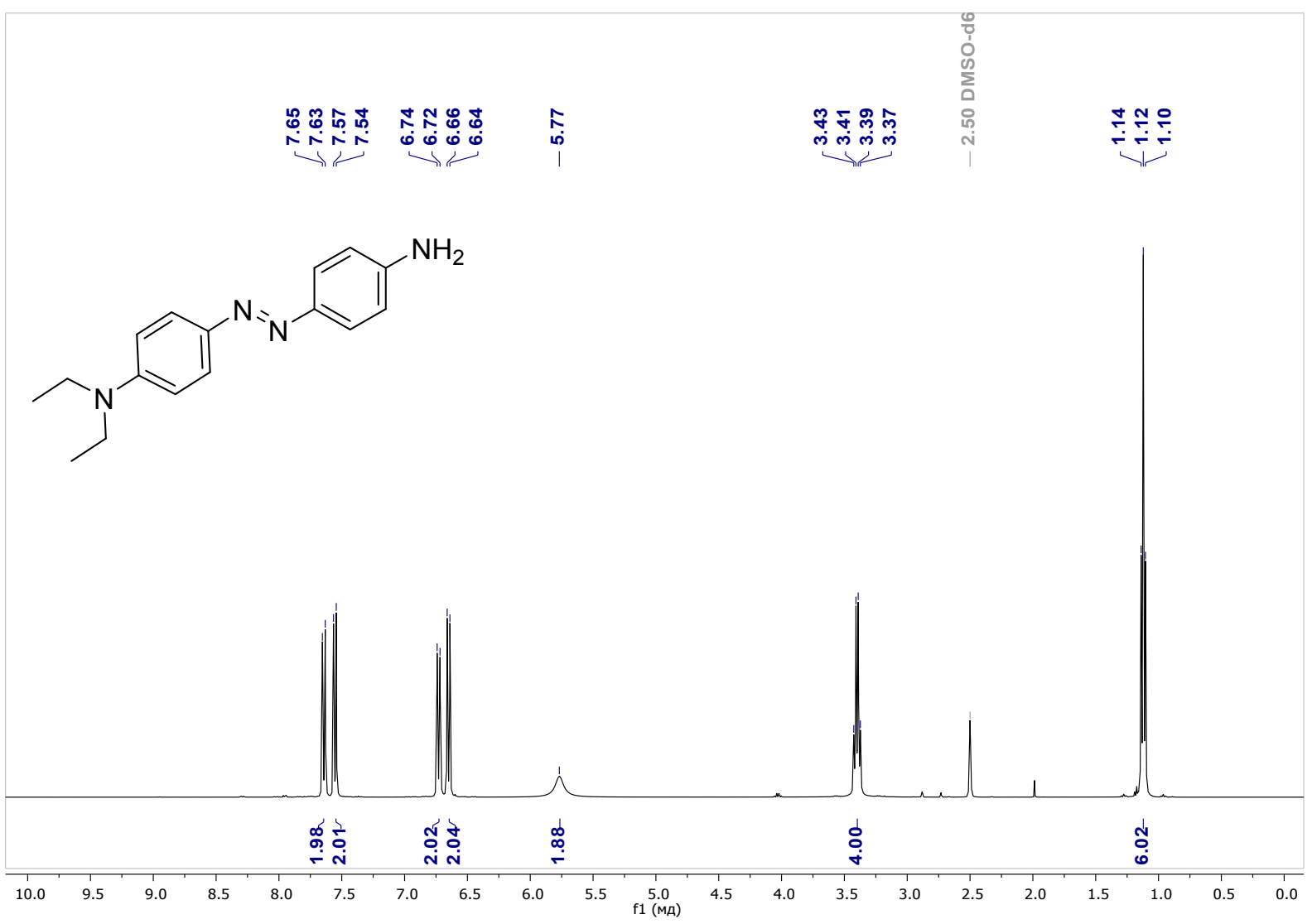

Figure S3. ${ }^{1} \mathrm{H}$ NMR (400MHz, DMSO-d6) spectrum for 3

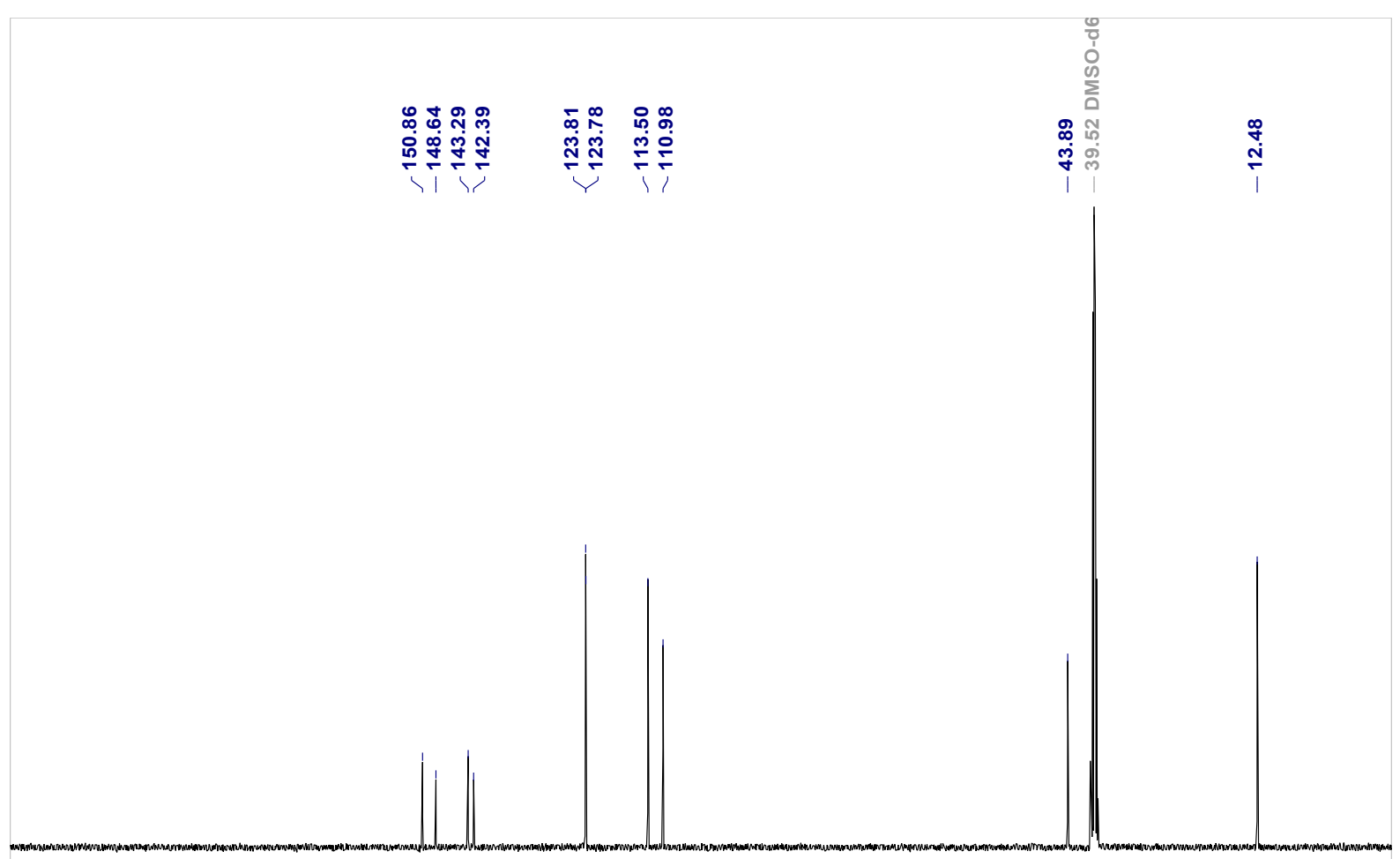

$\begin{array}{llllllllllllllllllllll}210 & 200 & 190 & 180 & 170 & 160 & 150 & 140 & 130 & 120 & \underset{\mathrm{f} 1}{110}(\mathrm{~mA}) & 90 & 80 & 70 & 60 & 50 & 40 & 30 & 20 & 10 & 0 & \end{array}$

Figure S4. ${ }^{13} \mathrm{C}$ NMR (101MHz, DMSO-d6) spectrum for 3 


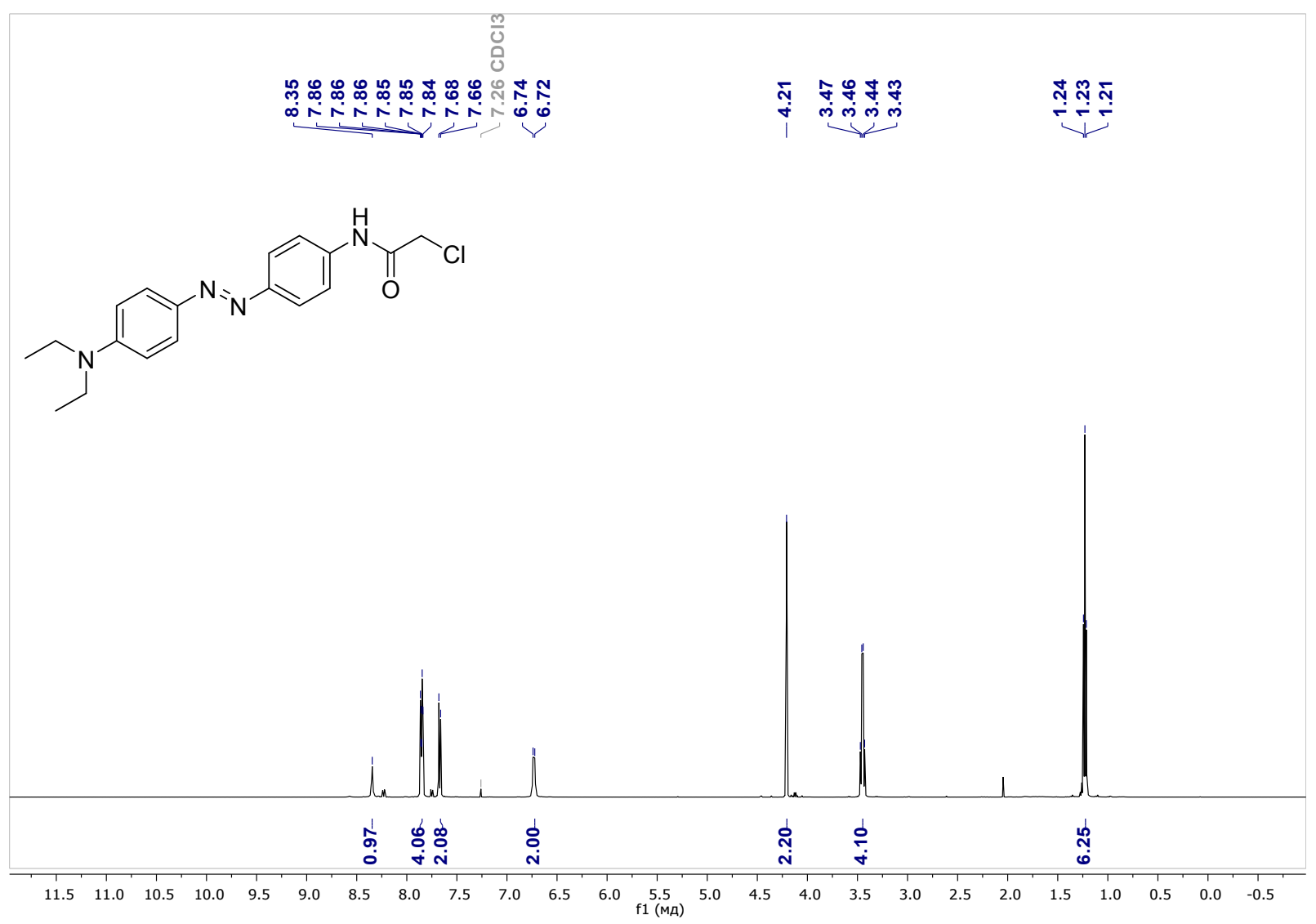

Figure S5. ${ }^{1} \mathrm{H}$ NMR (400MHz, $\left.\mathrm{CDCl}_{3}\right)$ spectrum for 4

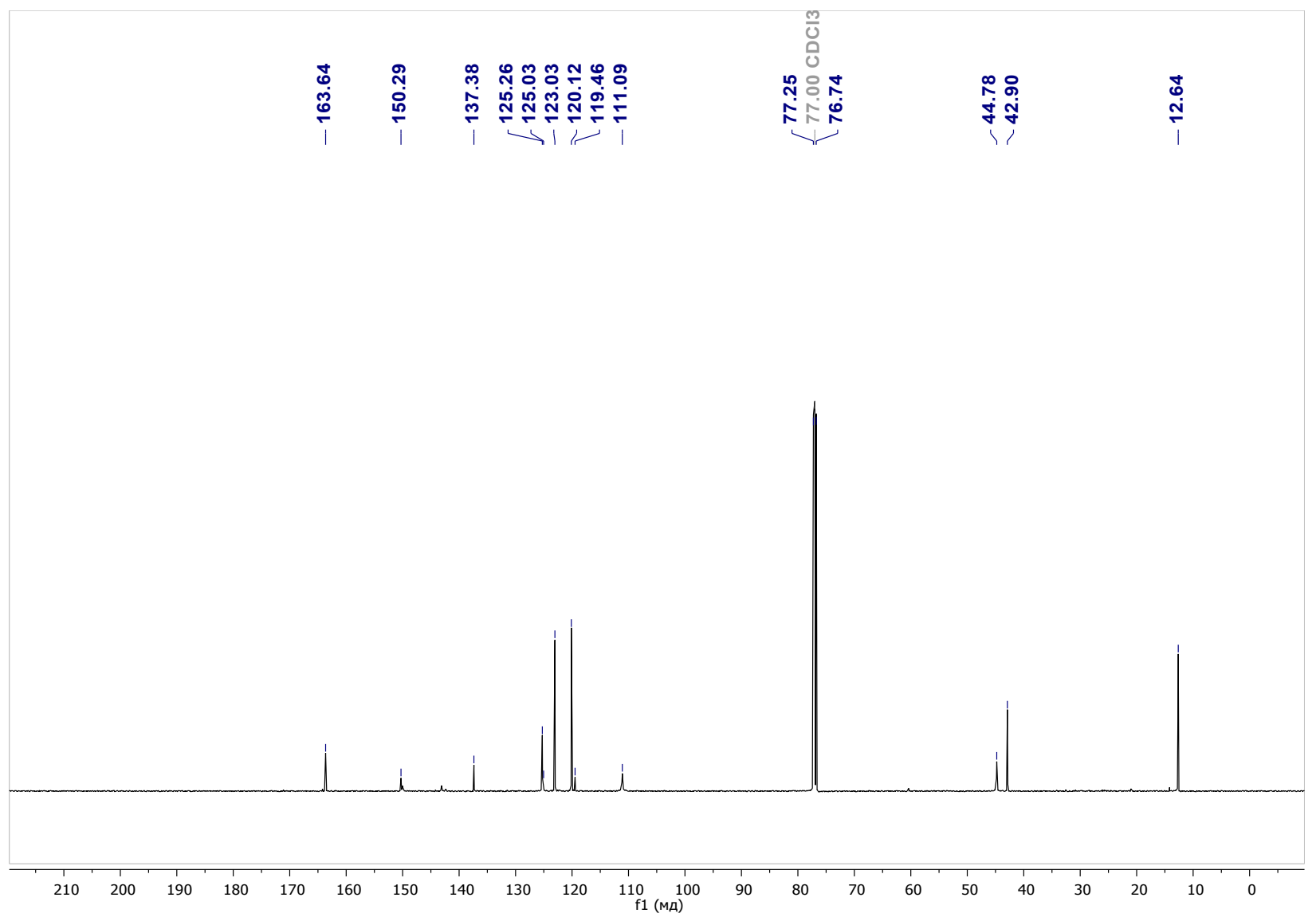

Figure S6. ${ }^{13} \mathrm{C}$ NMR $\left(101 \mathrm{MHz}, \mathrm{CDCl}_{3}\right)$ spectrum for 4 


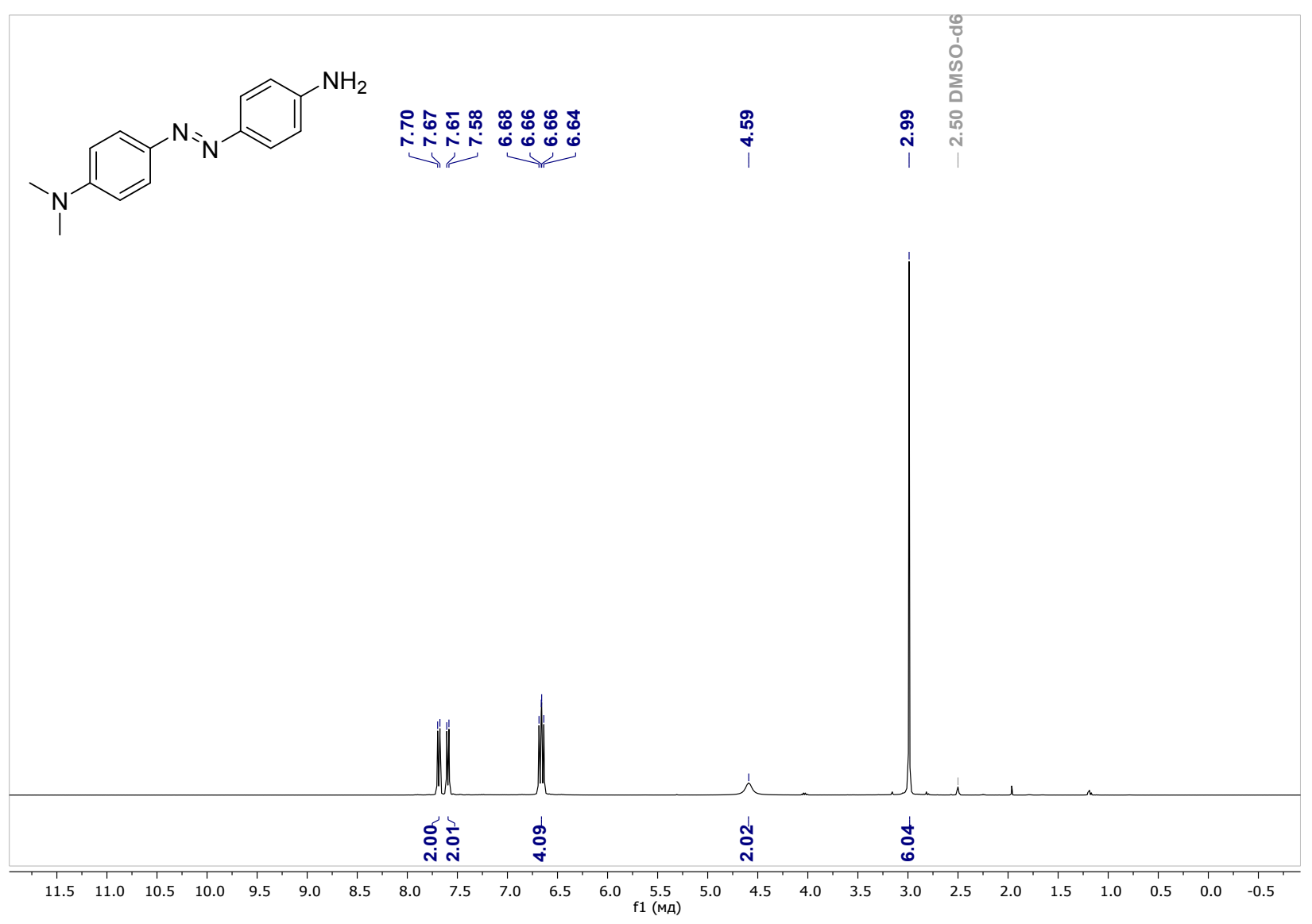

Figure S7. ${ }^{1} \mathrm{H}$ NMR (400MHz, DMSO-d6/CDCl 3 mixture) spectrum for 7

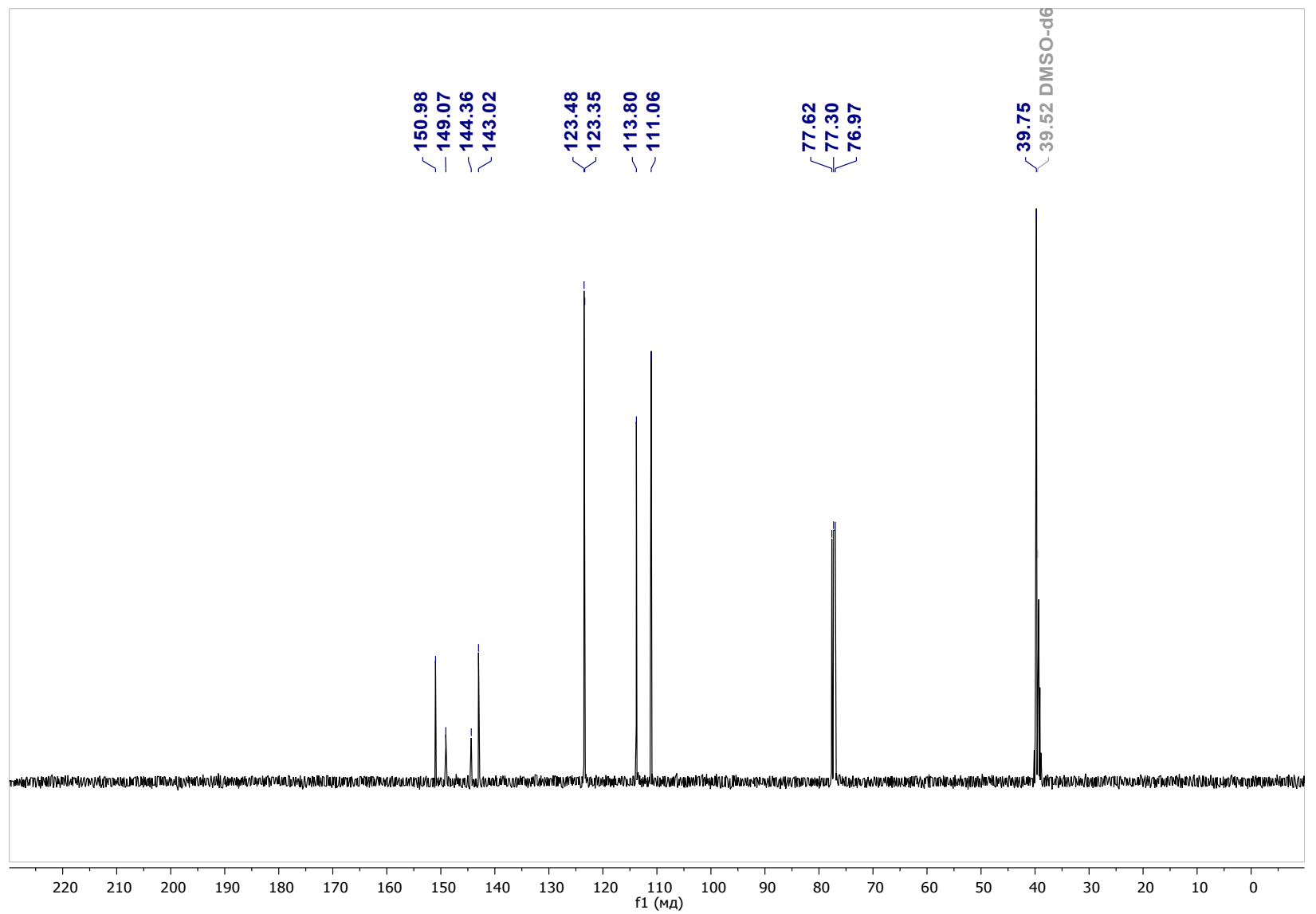

Figure S8. ${ }^{13} \mathrm{C}$ NMR (101MHz, DMSO-d6/CDCl ${ }_{3}$ mixture) spectrum for 7 


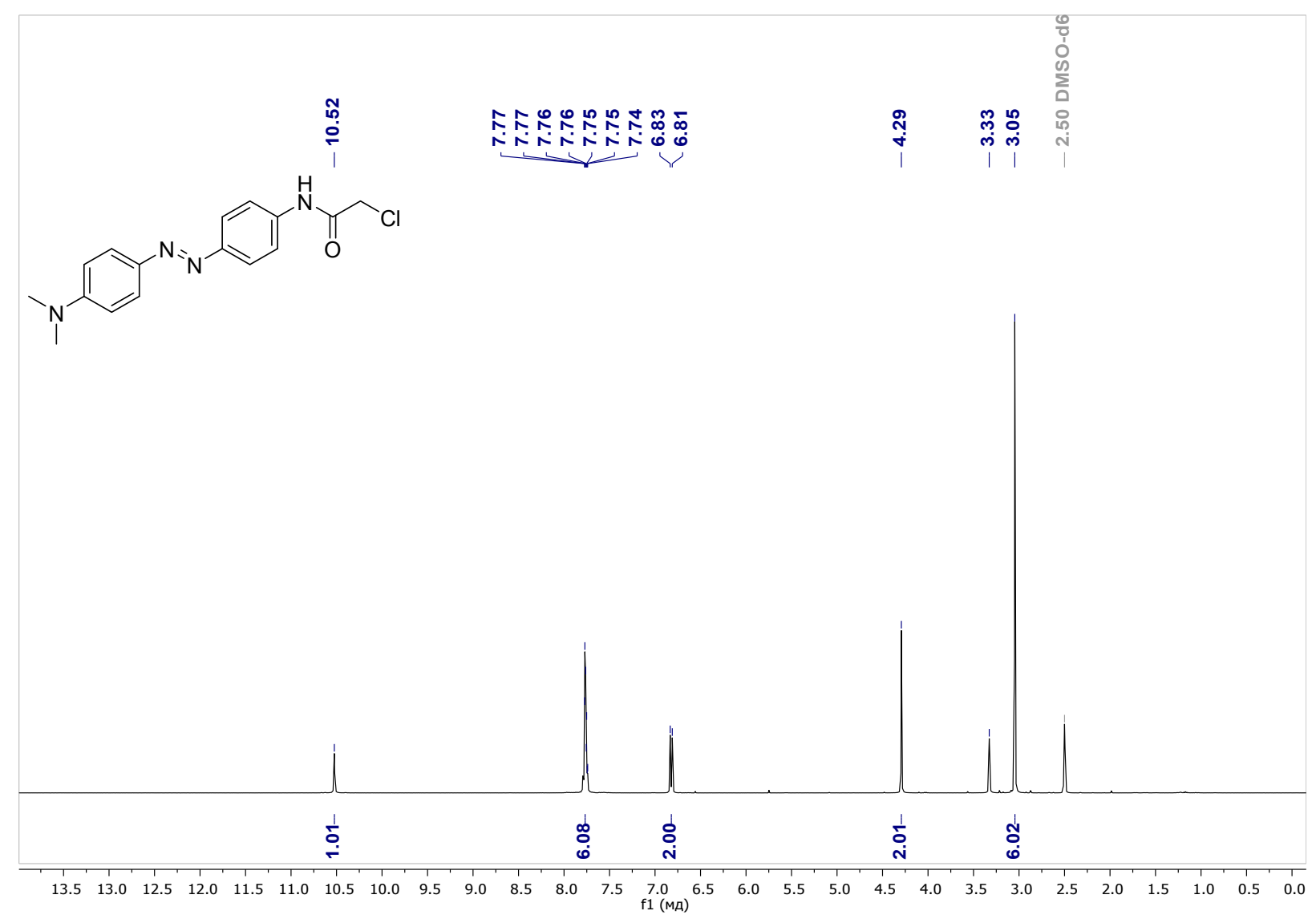

Figure S9. ${ }^{1} \mathrm{H}$ NMR (400MHz, DMSO-d6) spectrum for 8

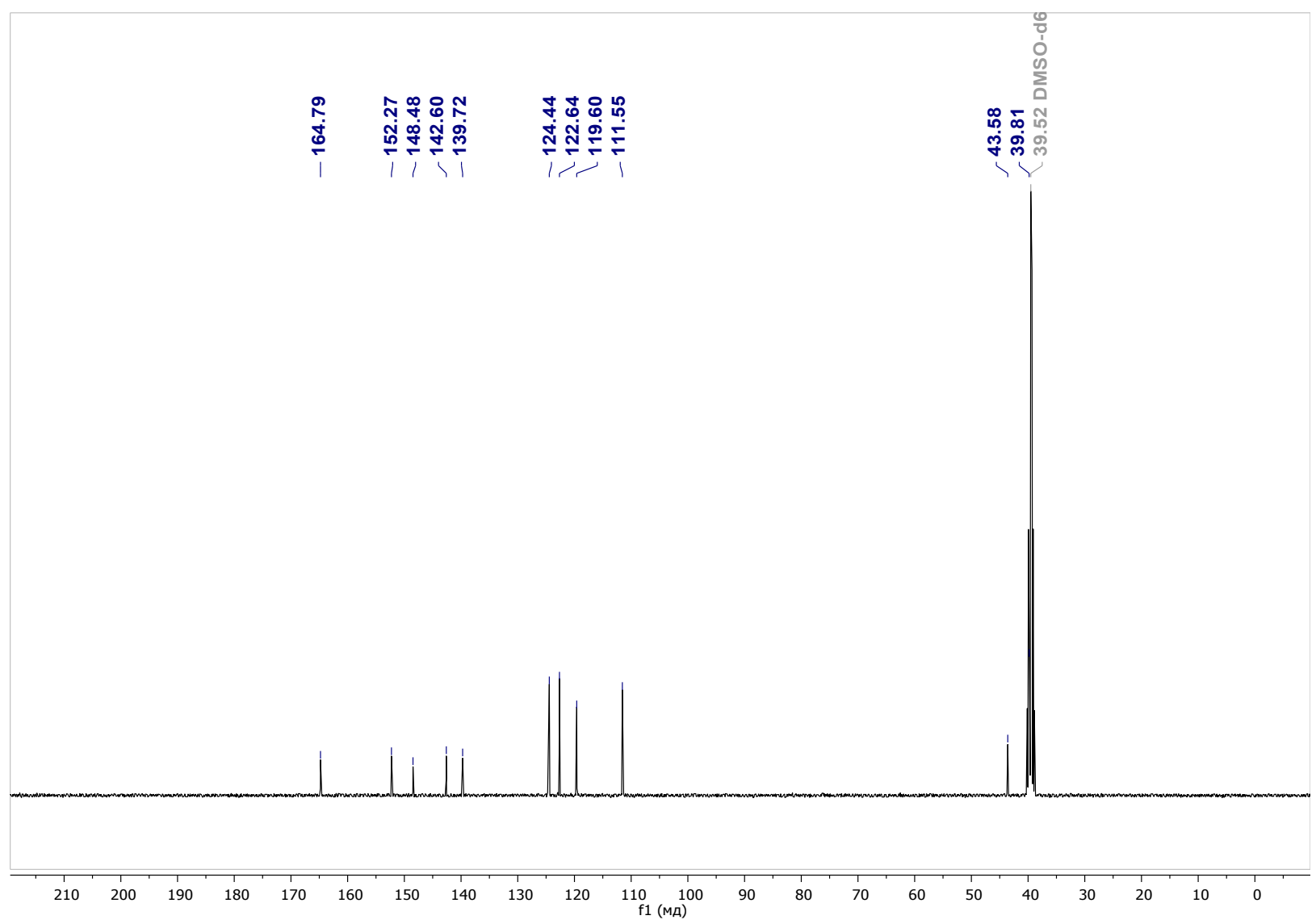

Figure S10. ${ }^{13} \mathrm{C}$ NMR (101MHz, DMSO-d6) spectrum for 8 


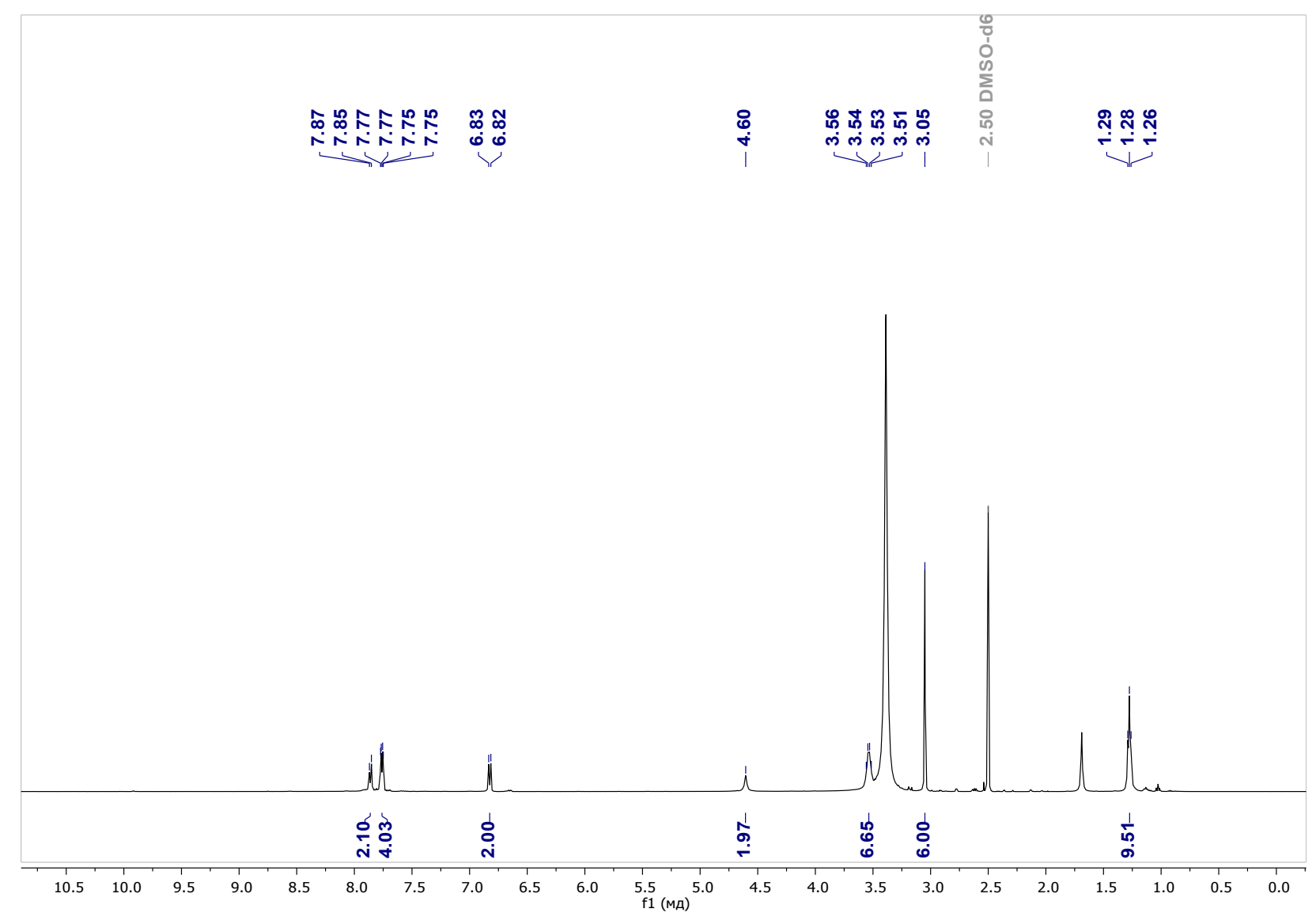

Figure S11. ${ }^{1} \mathrm{H}$ NMR (400MHz, DMSO-d6) spectrum for DMNAQ

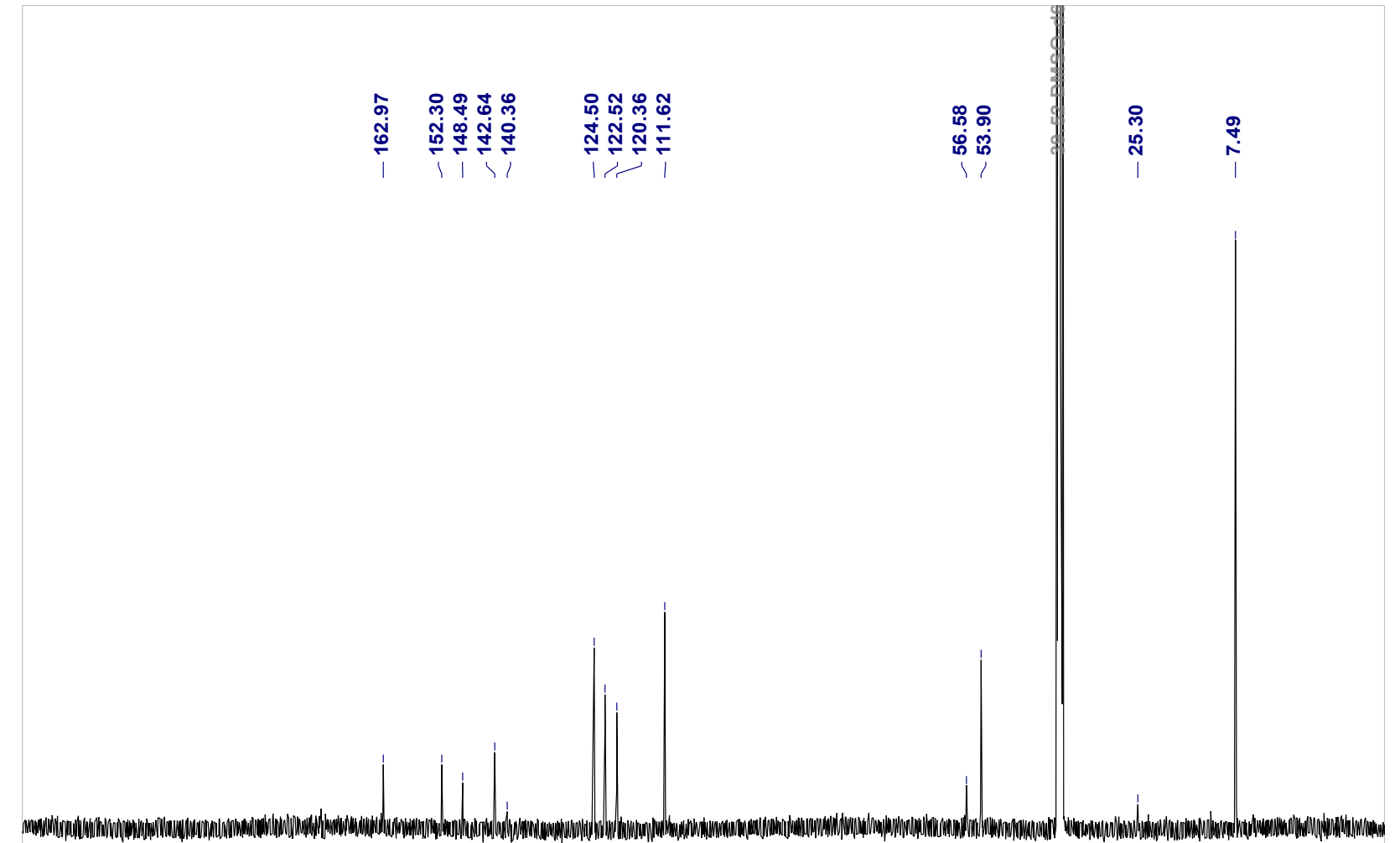

\begin{tabular}{|llllllllllllllllllllllllllll}
1 & 220 & 210 & 200 & 190 & 180 & 170 & 160 & 150 & 140 & 130 & 120 & 110 & 100 & 90 & 80 & 70 & 60 & 50 & 40 & 30 & 20 & 10 & 0 & -10 &
\end{tabular}

Figure S12. ${ }^{13} \mathrm{C}$ NMR (101MHz, DMSO-d6) spectrum for DMNAQ 


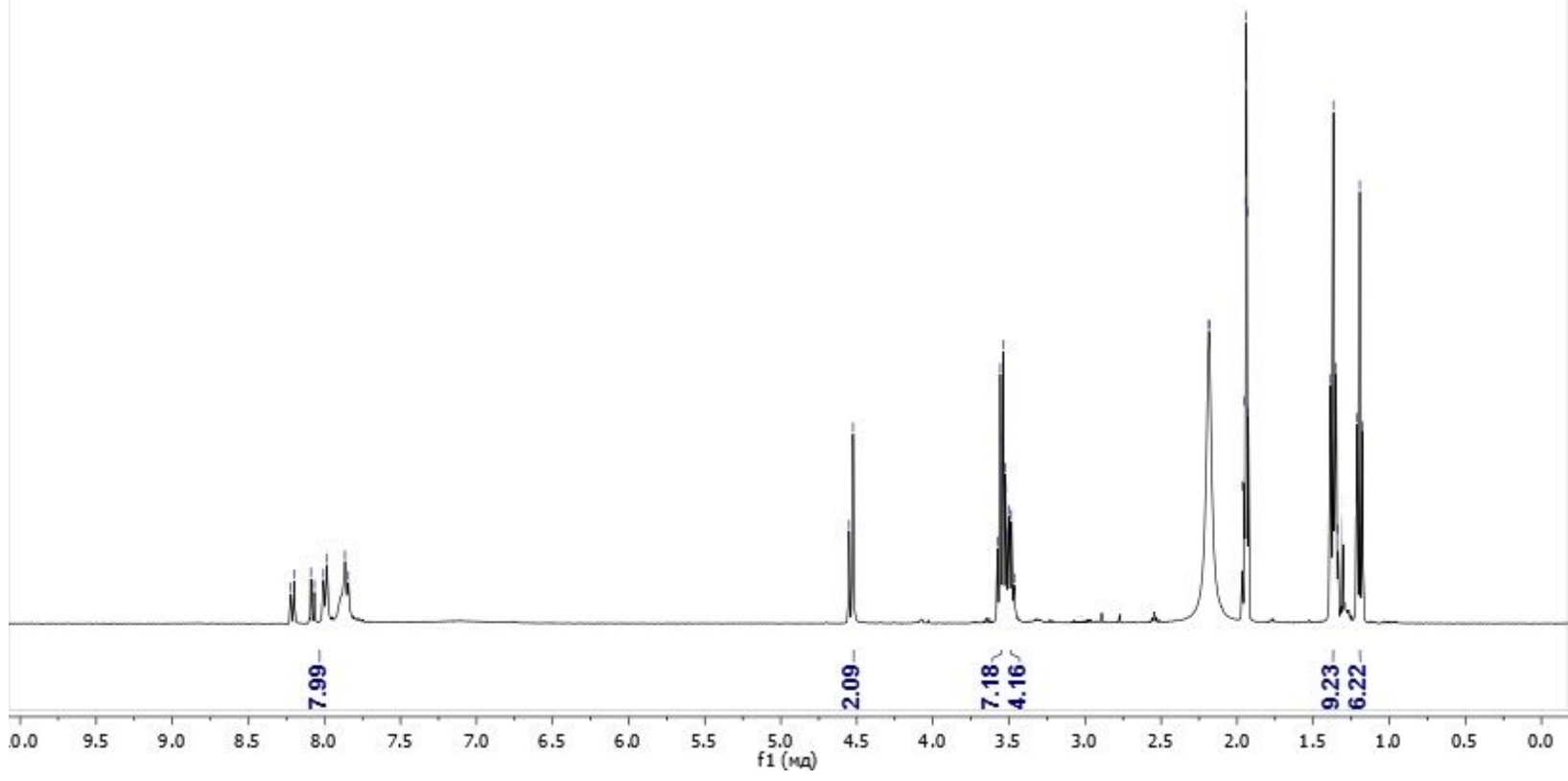

Figure S13. ${ }^{1} \mathrm{H}$ NMR (400MHz, DMSO-d6/CDCl ${ }_{3}$ mixture) spectrum for DENAQ

\section{Materials and Methods}

${ }^{1} \mathrm{H}$ and ${ }^{13} \mathrm{C}$ NMR spectra were recorded on a Bruker AVANCE III $\left(500 \mathrm{MHz}\right.$ for ${ }^{1} \mathrm{H}, 125$ $\mathrm{MHz}$ for ${ }^{13} \mathrm{C}$ ). Data was reported as follows: chemical shifts are reported in parts per million relative to the respective residual solvent peak as an internal standard. The following abbreviations were used: $\mathrm{s}$ - singlet, $\mathrm{d}$ - doublet, $\mathrm{t}$ - triplet, $\mathrm{q}$ - quartet, $\mathrm{bs}$ broad singlet, $\mathrm{m}$ - multiplet. High-resolution mass-spectra with Electrospray ionization (ESI) were measured on a Bruker MaXis mass spectrometer or Shimadzu Nexera LCMS9030 mass spectrometer. Thin-layer chromatography (TLC) was conducted on aluminum sheets precoated with $\mathrm{SiO}_{2}$ ALUGRAM SIL G/UV254. UV/Vis spectra were recorded on a NanoDrop 2000 spectrophotometer using $10 \mathrm{~mm}$ cuvette.

All commercially available reagents were purchased from Sigma-Aldrich, abcr $\mathrm{GmbH}$, TCI and used without further purification. Column chromatography was performed on silica gel $60 \mathrm{M}(0.04-0.063 \mathrm{~mm})$. Used solvents were anhydrous. 


\section{References}

1) Gao, Dan, et al. "Synthesis and measurement of solubilities of reactive disperse dyes for dyeing cotton fabrics in supercritical carbon dioxide." Industrial \& Engineering Chemistry Research 53.36 (2014): 13862-13870. 